\title{
Pitfalls of anticoagulation therapy in pregnant women with mechanical valve prostheses. The case of two thrombotic events during one pregnancy
}

\author{
Filip Koubek, Jiří Vejvoda, David Alan, Josef Veselka \\ Department of Cardiology, 2nd Faculty of Medicine and Motol University Hospital, Prague
}

\section{ARTICLE INFO}

Article history:

Submitted: 17. 4. 2018

Accepted: 17. 10. 2018

Available online: 16. 9. 2019

\section{Klíčová slova:}

Antikoagulace

Systémová trombolýza

Těhotenství

Trombóza chlopně

\section{SOUHRN}

U antikoagulovaných pacientů s mechanickou chlopenní protézou představuje heparin nadále jedinou možnou alternativu warfarinu, kterou volíme v některých specifických situacích. Jednou z takových situací je těhotenství vzhledem ke známému teratogennímu účinku warfarinu v závislosti na dávce. Během ambulantní léčby nízkomolekulárním heparinem je nutné pravidelně monitorovat její účinnost a rovněž je třeba mít na paměti odlišné cílové pásmo monitorovaného parametru, než jak je tomu u jiných diagnóz vyžadujících antikoagulační terapii. Přs pečlivou kontrolu je zde nemalé riziko selhání léčby, a to zejména vzhledem k nespolehlivé aplikaci léčiva $v$ ambulantních podmínkách a také vzhledem ke kolísání koncentrace léčiva při krátkém eliminačním poločasu. Tato kazuistika popisuje případ mladé ženy s mechanickou aortální protézou, která během jedné gravidity prodělala dvě trombotické príhody. První epizoda v úvodu těhotenství byla způsobena nevhodným antikoagulačním režimem. Druhá př́hoda nastala přes adekvátně vedenou léčbu nízkomolekulárním heparinem dle platných doporučení s pravidelnou monitorací účinnosti. V obou př́padech byla tato komplikace úspěšně léčena podáním systémové trombolýzy.

(c) 2019, ČKS.
Keywords:

Anticoagulation

Pregnancy

Systemic thrombolysis

Valve thrombosis

\begin{abstract}
In anticoagulated patients with mechanical valve prostheses, heparin is still the only possible alternative to warfarin that we choose in some specific situations. One such situation is pregnancy due to the known teratogenic effect of warfarin in a dose-dependent manner. During outpatient treatment with low molecular weight heparin, its efficacy should be monitored regularly and a different target range of the monitored parameter should be kept in mind than with other diagnoses requiring anticoagulation therapy. Despite careful control, there is a considerable risk of treatment failure, particularly due to the unreliable use of the drug in ambulatory conditions and also due to drug level fluctuations at a short elimination half-time. This case report describes the case of a young woman with a mechanical aortic prosthesis who experienced two thrombotic events during one pregnancy. The first episode at the beginning of pregnancy was due to an inappropriate anticoagulation regimen. The second event occurred through adequate treatment with low molecular heparin according to valid recommendations with regular monitoring of efficacy. In both cases, this complication was successfully treated by systemic thrombolysis.
\end{abstract}




\section{Introduction}

The valve prosthesis thrombosis is one of the most serious complications that can occur in patients with mechanical replacements in particular. Therefore, it is very important to regularly and consistently monitor the efficacy of anticoagulant therapy. Nowadays, in the era of NOACs boom, only two types of drugs, warfarin and heparin (in the form of both unfractionated and low molecular weight), are still available for patients with mechanical valves. Some clinical trials with NOACs ${ }^{1}$ in this indication had to be prematurely discontinued for an unfavourable efficacy and safety profile and, over the next few years, the list of available preparations is unlikely to expand. Thus, warfarin remains the drug of choice for long-term treatment of patients with mechanical valve prostheses. In cases where coagulation parameters have to be temporarily normalized (e.g. surgery, intervention, delivery, etc.), heparin is used due to its appropriate pharmacokinetic and pharmacodynamic properties (rapid onset and discontinuation).

The specific situation that this publication discusses is anticoagulation therapy in pregnant women with mechanical valve prostheses. It is known that warfarin therapy, depending on the daily dose, carries a certain risk of congenital foetal developmental defects. ${ }^{2}$ The most vulnerable period is the 1st trimester when embryogenesis and formation of the bases of individual organ systems take place. Therefore, at least during this period, but preferably before pregnancy (during pregnancy planning), warfarin should be replaced with heparin. ${ }^{3}$

This case report describes the case of a young pregnant woman with mechanical prosthesis in the aortic position whose pregnancy was complicated by two thrombotic events.

\section{Case description}

This is a 27-year-old woman with congenital aortic stenosis. In 2000, balloon valvuloplasty was performed in her. In 2007, the patient suffered from endocarditis of aortic valve, and therefore underwent a valve replacement with mechanical prosthesis in the same year. In the following years, the patient underwent several thromboembolic events. One of them was an ischemic stroke with magistral cerebral artery occlusion with the necessity of intravenous thrombolysis (IVT). In other cases it was transient ischemic attacks (TIA) with ad integrum normalisation without the use of IVT. In all cases, ineffective anticoagulation with warfarin (INR <2.0) was proven.

During the two-year follow-up in our ambulance, we no longer observed any thromboembolic complications. The patient regularly received warfarin with adequate coagulation tests, the results of which consistently moved within the recommended target range (INR $\geq 2.0$, median INR 3.0). ${ }^{3}$

This time, the patient came to our ambulance for unplanned control in the 7th week of pregnancy to consult for further care, including anticoagulation treatment. Based on the recommendation of her GP, immediately after the gravity test positivity (2 weeks before our examination), she dropped warfarin and replaced it with the prescribed low molecular weight heparin $(\mathrm{LMWH})$, namely with the preparation of bemiparin (Zibor) at the dose of $2500 \mathrm{IU}$ (international units) anti-Xa every $24 \mathrm{~h}$.

Throughout the time (using prescribed LMWH), the patient was completely asymptomatic (without breathing difficulties, stenocardia, palpitations, syncope, or neurological symptoms). Physical examination revealed a noisy systolic murmur with a peak in the aortic mouth area. The other physical findings were normal except for obesity. The basic measured values - blood pressure (BP) and pulse were 140/95 $\mathrm{mmHg}$ and $76 \mathrm{bpm}$ resp.; ECG curve without acute pathology (sinus rhythm, standard intervals' length, ST without denivelation, no T wave inversion). The baseline echocardiography showed an elevated prosthetic aortic valve gradient $(56 / 33 \mathrm{mmHg}$ - maximal/ mean gradient) and only slight regurgitation. In comparison, the gradient measured at the previous routine check was $24 / 13 \mathrm{mmHg}$. We hospitalized the patient and started anticoagulation treatment with low molecular weight heparin (enoxaparin, Clexane) at full dose according to valid ESC recommendations ${ }^{3}$ with anti-Xa activity monitoring (Clexane $1.4 \mathrm{ml}$ every 12 hours followed by a dose increase of $1.6 \mathrm{ml}$ every 12 hours, anti-Xa of $1.13 \mathrm{IU} / \mathrm{ml}$ ). Transoesophageal echocardiography (TOE) confirmed a finding of the aortic prosthesis dysfunction; however, no flutter formation (thrombus) was identified. As the echocardiographic finding was not changed within 7 days, we started - based on the Heart Team's decision and after interview with the patient - an application of intravenous thrombolysis (IVT). This procedure was performed in a catheterization laboratory with the Filterwire protection system introduced into both internal carotid arteries (transfemoral approach) under the skiagraphic control to eliminate the risk of severe embolization into the central nervous system. First, a bolus of $15 \mathrm{mg}$ rt-PA (Actilyse) was administered, followed by a continuous dose infusion of $85 \mathrm{mg}$ for 80 minutes. During the course of the procedure, unfractionated heparin was administered (intravenously) at a total dose of 8,000 IU.

Immediately after the completion of IVT, a decrease of transvalvular maximal (echocardiographic) gradient was observed (from $50 \mathrm{mmHg}$ to $32 \mathrm{mmHg}$ ). During this procedure, we did not experience any bleeding or thromboembolic complications. Subsequently, we continued the anticoagulation treatment of LMWH with anti-Xa activity monitoring (Clexane $1.6 \mathrm{ml}$ every 12 hours, anti-Xa always in the range of 1.0-1.2 IU/ml). The next day after IVT, the patient was released to outpatient care and continued the established anticoagulation regime. Regular echocardiographic examinations were performed at a 2-week interval with relatively favourable flow parameters of aortic prosthesis (measured gradients ranging from 32/13 $\mathrm{mmHg}$ to $43 / 25 \mathrm{mmHg}$ ). We also monitored the anti-Xa activity, the values of which were always in the target range or higher (anti-Xa $\geq 1.0 \mathrm{IU} / \mathrm{ml}$ ). The patient continued to be asymptomatic without significant haemorrhagic manifestations, and gynaecological controls confirmed a thriving pregnancy.

One of the regular check-ups (23rd week of pregnancy) revealed a recurrent increase of the transaortic systolic 
gradient $(74 / 43 \mathrm{mmHg})$ and a moderate aortic regurgitation was evident. Even in this case, the patient denied any cardiac or neurological symptoms. Physically there was again a noisy systolic murmur with a maximum in the area of the aortic mouth listening point (2nd limb on the right parasternal) and also a new decrescendo diastolic murmur with the maximum on the left parasternal. The other physical findings were unchanged. Basic measured quantities, BP and pulse, were $120 / 80 \mathrm{mmHg}$ and $96 \mathrm{bpm}$, respectively; the ECG curve without acute pathology (sinus rhythm, standard intervals, ST without denivelation, no $\mathrm{T}$ wave inversion). So we hospitalized the patient again, and after the patient had been instructed, based on the Heart Team's recommendation, we started IVT early. This time, a different protocol for the administration of rt-PA (Actilyse) was chosen - an extended, fractioned $25 \mathrm{mg}$ dose schedule within 6 hours with a $50 \mathrm{mg} / \mathrm{h}$ increase in speed and with continuous echocardiographic effect monitoring. During IVT, we applied a total of $175 \mathrm{mg}$ rt-PA (Actilyse) over 4 days. The transaortic gradient of $47 / 26 \mathrm{mmHg}$ was measured by the time of the patient release, while a mild aortic regurgitation was present. After IVT, we continued the anticoagulation treatment with unfractionated heparin and began warfarin saturation with the addition of a low dose of antiaggregant (acetylsalicylic acid [ASA], $100 \mathrm{mg} /$ day). We released the patient to the outpatient care at the effective INR of 2.8. Even during this second thrombolytic procedure, we did not identify any significant bleeding or thromboembolic complications. The control gynaecological examination again showed a normal thriving pregnancy.

Subsequent outpatient tests repeatedly measured favourable parameters of the aortic prosthesis (transaortic gradient ranging from $34 / 17 \mathrm{mmHg}$ to $38 / 18 \mathrm{mmHg}$, only a slight regurgitation was present). Coagulation tests were also in the target range or higher (INR 2.6-3.7). After consulting the dispensary gynaecological clinic, we ended ASA treatment at 32 weeks of pregnancy, and replaced warfarin with LMWH at 36 weeks with anti-Xa monitoring (Clexane $1.6 \mathrm{ml}$ every 12 hours, anti-Xa 1.29 $\mathrm{IU} / \mathrm{ml}$ ). In the 39th week of pregnancy, the patient underwent her planned section of healthy female foetus. The early postpartum period was complicated by bleeding in the area of the operation wound (the source found in the subcutis) with the need for surgical revision and the substitution of blood derivates. In the following days, no complications occurred and on the eighth day after the section the patient was released home with LMWH therapy at the initial dose.

The outpatient check carried out 4 weeks after the section showed a steady positive aortic prosthesis finding (gradient 30/16 mmHg, slight regurgitation). The flow parameters approximately corresponded to the values measured before pregnancy. The optimal condition of the surgical wound allowed for the re-deployment of warfarin (target INR $\geq 2.0$, median INR 3.0). During the next inspection after 4 weeks, we found an identical echocardiographic finding and the patient had already been adequately warfarinised according to our recommendations.

\section{Conclusion}

This relatively dramatic case report with a good end has confirmed the validity of several facts in practice:

First of all, pregnancy in mechanical valve prosthesis wearers is generally a high-risk situation, and although the presence of this prosthesis is not an absolute contraindication of pregnancy, the patient should be alerted to the imminent complications (especially thrombotic) beforehand and motivated to work closely together to ensure optimal anticoagulation treatment.

Secondly, immediately after stopping warfarin (if indicated), ${ }^{3}$ an adequate LMWH treatment, i.e. 12-hour dose with anti-Xa guided adjustment should be initiated, rather than rely on dose choice according to patient weight or even choose other regimes (e.g. 24-hour dose). In addition, it is necessary to respect the different (higher) anti-Xa activity target range in this indication in pregnant women. $^{3}$

Thirdly, even with the utmost effort for effective anticoagulation of LMWH (patient education, frequent anti$\mathrm{Xa}$ controls), it is necessary to recognize the limitations of this drug - especially relatively short half-time, fluctuating efficacy (low activity at the end of the dosing interval), and, particularly, unreliable bioavailability during subcutaneous administration.

Fourthly, systemic thrombolysis in pregnant women with thrombotically impaired mechanical valves is probably a relatively safe treatment method with an acceptable risk of complications for both the mother and the foetus, which is in line with the valid recommendations of the European Society of Cardiology. . $^{3,4}$

Fifthly, it is advisable for young women (planning a pregnancy) to recommend a biological prosthesis replacement ${ }^{3}$ if needed, despite the disadvantage of a future reoperation necessary (or likely).

\section{Conflict of interest}

None declared.

\section{Funding body}

None.

\section{Ethical statement}

Authors state that the research was conducted according to ethical standards.

\section{References}

1. Eikelboom JW, Connolly SJ, Brueckmann M, et al. Dabigatran versus Warfarin in Patients with Mechanical Heart Valves. N Engl J Med 2013;369:1206-1214.

2. Hall JG, Pauli RM, Wilson KM. Maternal and fetal sequelae of anticoagulation during pregnancy. Am J Med 1980;68: 122-140.

3. Regitz-Zagrosek V, Roos-Hesselink JW, Bauersachs J, et al. ESC Guidelines on the management of cardiovascular diseases during pregnancy. Eur Heart J 2011;32:3147-3197.

4. Baumgartner H, Falk V, Bax JJ, et al. 2017 ESC/EACTS Guidelines for the management of valvular heart disease. Eur Heart J 2017;38:2739-2786. 